\title{
Preface: ADAPTA-adaptations of aquatic biota of the Amazon
}

\author{
Adalberto Luis Val • Gudrun De Boeck
}

Received: 13 September 2016/ Accepted: 20 October 2016/Published online: 1 November 2016

(C) Springer International Publishing Switzerland 2016

Mitigation and adaptation to environmental changes, including global warming, are currently on the agenda in all countries. Our everyday life requires now, more than ever before, a direct action to reduce environmental degradation. It affects both the economy, particularly in developed countries, and the dependence on natural resources, particularly in developing countries. Definitely, environmental changes are affecting every single ecosystem in the planet, even the more pristine ones, such as the Amazon, and are defining one of the biggest challenges of the twentyfirst century.

The Amazon is a land of diversities, i.e., an amphibious land where a colossal diverse environment supports a massive biological diversity unparalleled on our planet. The environmental diversity includes waters of different colors (white, black, and clear), as

Guest editors: Adalberto L. Val, Gudrun De Boeck \& Sidinei M. Thomaz / Adaptation of Aquatic Biota of the Amazon

\section{A. L. Val ( $\square)$}

Laboratory of Ecophysiology and Molecular Evolution, Brazilian National Institute for Research in the Amazon, André Araújo Avenue, 2936, Petrópolis, Manaus, AM 69067-375, Brazil

e-mail: dalval@inpa.gov.br

G. De Boeck

SPHERE, Department of Biology, University of Antwerpen, Groenenborgerlaan 171, 2020 Antwerp, Belgium described by the pioneer Harald Sioli (1950), running from the Andean mountains down to the Atlantic Ocean, where the Amazon river itself discharges near $20 \%$ of all freshwater entering oceans worldwide. On their way to reach a tributary or the main channel, the waters interact with diverse forests and soil types, being influenced by the physical and chemical characteristics of the place. In addition to the tremendous spatial variability, the waters of the Amazon are subjected to a considerable seasonal variation of river water level, the so-called river water pulses (Junk et al., 1989; Schöngart \& Junk, 2007). Therefore, these water types present significant differences in temperature, low to very low levels of dissolved oxygen, acidic $\mathrm{pH}$ associated with reduced ion concentrations, high levels of hydrogen sulfide, especially in the floodplain areas (várzea) along the white-water rivers, among other characteristics (Val \& Almeida-Val, 1995).

There are more than 3,000 known fish species living in Amazon waters. These fish species developed a wide range of adaptations at all levels of the biological organization to thrive in these dynamic extreme environments (Val \& Almeida-Val, 1995; Gonzalez et al., 1998; Wood et al., 1998; Barletta et al., 2010; Duarte et al., 2013; Kochhann et al., 2013; Val et al., 2015; Prado-Lima \& Val, 2016). Similarly, these adaptations to local conditions have been described for microorganisms, fungi, plankton, algae, plants, insects, crustaceans, amphibians, and a 
multitude of aquatic invertebrates (Couceiro et al., 2011; Junk et al., 2011; Franco-de-Sá \& Val, 2014; Hamada et al., 2014; Lopes et al., 2016a). However, will these adaptations and abilities allow these organisms to survive future environmental changes, which make their environments even more challenging?

The genome of these species contains a phenomenal set of information generating a tremendous biological diversity, which is amplified in the Amazon, particularly in the aquatic environment. Can regulation of the expression of such genetic information, which allowed life to cope with past environmental variations, safeguard life under the ongoing environmental challenges? No appropriate answer is available, but we have learned during the last decades that many fish species of the Amazon are already near their environmental tolerance limits (Val \& AlmeidaVal, 1995; Wood et al., 1998; Campos et al., 2016).

The speed at which these environmental changes take place nowadays causes concern. It took millions of years for aquatic life to evolve a genome compatible with their environmental demands. Today, with the exception of a few pristine environments, the vast majority of the bodies of water on the planet display profound changes within a short period of time, i.e., within a year or few years. Can the existing genome be modulated to ensure a rapid adjustment to these continuous short-term environmental changes, particularly related to the effects of climate change?

ADAPTA is a long-term project funded by the Brazilian government, which aims to investigate the adaptations of the aquatic biota of the Amazon. Seventeen research groups from Brazil and from several other countries joined the project during the last 6 years, to investigate many characteristics of the Amazonian aquatic life and their environments. The ADAPTA team has published hundreds of papers worldwide, contributing towards answering the questions listed above. As expected, each question addressed gave rise to many new ones. Many of these new questions, which will be dealt with in a new phase of the program, are related to conservation and recovery of degraded aquatic environment, a further investigation on abilities of fish of the Amazon to regulate their genome under the never ending environmental changes, and the potential social disturbances caused by environmental degradation. In addition, as the analysis of the effects of climate change progresses and uncovers new challenges
(Nelson \& Val, 2016; Val et al., 2016), efforts will continue to clearly describe the consequences for biota in the Amazon.

This special issue of Hydrobiologia contains a new set of papers related to the ADAPTA program. This set of papers includes a fascinating analysis of the acidic and ion-poor water of Rio Negro (Johannsson et al., 2016). The authors clearly evidenced the terrigenous origin of the dissolved organic carbon (DOC), with high aromaticity, high capacity to produce reactive oxygen species (ROS), high tryptophan-like fluorescence, and appreciable rates of photo-oxidation. Surprisingly, no oxidative stress was observed for the analyzed fish species. In connection with these findings, Martins et al. (2016) analyzed the effects of climate change on leaf breakdown by microorganisms and reported an increase of leaf breakdown by microorganisms relative to shredders breakdown activity. According to these authors, the future climate scenarios would cause disturbances in the pathways of organic matter processing with significant effects on water characteristics and aquatic food webs.

Another connected issue is the analysis of the regional- and local-scale distribution of two aquatic macrophyte species of the genus Montrichardia: $M$. linifera (Arruda) Schott and M. arborescens (L.) Schott (Lopes et al., 2016b). The authors showed that largescale distribution is determined by altitude, precipitation, and temperature of the driest month, characteristics that are climatically driven, while local gradients of water $\mathrm{pH}$, conductivity, and water transparency determine local-scale distribution. Thus, while the regional distribution is connected to the severity of global change, local distribution could be additionally disturbed by local anthropogenic activities.

Life in freshwaters demands the ability to take up essential ions from aquatic habitats that vary both spatially and seasonally. Analysis of physiological processes involved with ion homeostasis in organisms occurring in the Amazon supports analysis of how they can cope with anthropogenic environmental changes. The contribution of Lucena et al. (2016) brings an elegant analysis of the effects of exogenous biogenic amines on gill $\mathrm{Na}^{+}-\mathrm{K}^{+}$ATPase of the Amazonian shrimp Macrobrachium amazonicum, Heller, 1862. According to these authors, the effects are life-stage specific.

What can we say about closely related species thriving in different waters of the Amazon? Barros 
et al. (2016) mapped $45 \mathrm{~S}$ and $5 \mathrm{~S}$ ribosomal genes in the chromosomes of seven species of Anostomidae, a family of fishes widespread across the Amazon. They confirmed that, despite the conserved macrostructure of their chromosomes, the distribution of their heterochromatin is different. How this difference contributes to their ability to inhabit the different types of waters of the Amazon remains an open question.

A pair of papers focusing on carbohydrate metabolism showed the abilities of two groups of fish of the Amazon to maintain homeostasis under different environmental and diet conditions. MacCormack et al. (2016) studied how hypercarbia, a common situation in many water bodies of the Amazon, which is prone to be exacerbated as a consequence of climate changes, affects cardiac contractility and carbohydrate metabolism. The authors suggest that activation of $\mathrm{HCO}_{3}{ }^{-}$synthesis decreases glucose utilization and as such enhances carbohydrate stores, providing protection against hypoxia, a situation often encountered by the bottom-dwelling fish species that were analyzed. Concurrently, Speers-Roesch et al. (2016) analyzed the capacity for de novo glucose synthesis (gluconeogenesis) in species of pacus and piranhas that present diverse dietary preferences, i.e., from the herbivorous or frugivorous pacus to the omnivorous or carnivorous piranhas. The authors showed that the observed interspecific variation was not related to dietary preference. The authors suggest that this characteristic would be a consequence of the plasticity of the animals in their dynamically changing environments.

Another pair of papers had an analysis of the metabolic rate of three small-sized fish species of the Amazon in common, when experimentally exposed to different challenges. In the first paper (Kochhann \& Val, 2016), the effect of habitat complexity on the relationship between metabolic rate and social status of the Amazonian dwarf cichlid Apistogramma agassizii, Steindachner, 1875, was investigated. The authors clearly showed that habitat structure interferes with behavioral characteristics in social hierarchies, consequently affecting the metabolic rate. In the second paper, Campos et al. (this volume) investigated the metabolic rate and thermal tolerance of two congeneric species of Paracheirodon: P. axelrodi, Schultz, 1956; and $P$. simulans, Géry, 1963. They concluded that despite the sympatric occurrence of these species, the higher metabolic capacity of $P$. simulans enables this species to better survive acutely higher temperatures in nature.
These two papers suggest that at least two physical characteristics of the habitat, physical structure and temperature, both prone to be affected by climate changes, affect metabolic rate.

In addition, fish commonly encounter some toxic substances in their habitats and the toxicity of these substances could be influenced by habitat characteristics. This special issue of Hydrobiologia includes two papers related to this subject. One analyzes the sensitivity to ammonia in eleven fish species of the Amazon (Souza-Bastos et al., 2016). The authors confirmed that fish of the Amazon are more sensitive to ammonia than freshwater species from other water basins. They showed also that hypoxia exacerbates the ammonia toxicity at least for the most sensitive species analyzed, $P$. axelrodi. In an accompanying paper, Braz-Mota et al. (2016) showed that toxicity of waterborne copper is further increased in the presence of high temperatures. They observed an increased imbalance of the antioxidant system reducing survival time of the animals. Again, climate changes affecting basic characteristics of water bodies could directly disrupt physiological and biochemical processes causing death.

Disturbances of aquatic biota also disturb basic needs of humans, particularly in tropical regions such as the Amazon. The tambaqui is the most important food fish in the region and the drastic environmental scenarios forecasted by IPCC (2007) clearly affect growth performance of this species. The extreme environmental scenarios cause an increase of food intake and decreased growth rate of the animals. This means that more effort is needed to maintain fish production in captivity; and in nature it is suggested that an ecological imbalance in the food web would take place (Oliveira \& Val, 2016).

Additionally, disturbances of aquatic biota would cause imbalances of populations of Amazonian disease vectors, particularly those of Anopheles darling Root, 1926, the malaria vector (Tadei et al., 2016). The authors analyzed several aspects of the biology of this species at different life stages and clearly showed that the future environmental scenarios will impose new challenges to control malaria in the Amazon.

In conclusion, this special issue of Hydrobiologia brings a set of articles showing how sensitive the Amazonian aquatic biota already are to the current natural environmental changes and how this sensitivity will be exacerbated under the environmental 
conditions predicted for the near future. It is noteworthy that the future biological scenarios are not complete as the interaction among the organisms at the ecological level, and between the many interacting physiological and biochemical processes within the organisms, is not completely understood, in particular for the aquatic biota of the Amazon. Thus, this special issue is a glimpse of what we have learned about the adaptations of the aquatic biota of the Amazon and, simultaneously, a set of primary information for future studies.

Acknowledgements The INCT ADAPTA (phase I) was supported by a joint grant from the Brazilian National Research Council (CNPq, process 573976/2008-2) and from the Amazonas State Research Foundation (FAPEAM, process 06.03159/2008) to ALV. Several side grants additionally supported research groups, individually acknowledged in the papers. ALV was the recipient of a research fellowship from the Brazilian CNPq.

\section{References}

Barletta, M., A. J. Jaureguizar, C. Baigun, N. F. Fontoura, A. A. Agostinho, V. M. F. Almeida-Val, A. L. Val, R. A. Torres, L. F. Jimenes-Segura, T. Giarrizzo, N. N. Fabré, V. S. Batista, C. Lasso, D. C. Taphorn, M. F. Costa, P. T. Chaves, J. P. Vieira \& M. F. M. Corrêa, 2010. Fish and aquatic habitat conservation in South America: a continental overview with emphasis on neotropical systems. Journal of Fish Biology 76: 2118-2176.

Barros, L. C., P. M. Galetti Jr \& E. Feldberg, 2016. Mapping 45S and $5 \mathrm{~S}$ ribosomal genes in chromosomes of Anostomidae fish species (Ostariophysi, Characiformes) from different Amazonian water types. Hydrobiologia. doi:10.1007/ s10750-015-2583-8.

Braz-Mota, S., L. M. L. Fé, F. A. C. Delunardo, H. SadauskasHenrique, V. M. F. Almeida-Val \& A. L. Val, 2016. Exposure to waterborne copper and high temperature induces the formation of reactive oxygen species and causes mortality in the Amazonian fish Hoplosternum littorale. Hydrobiologia. doi:10.1007/s10750-016-2847-y.

Campos, D. F., T. F. Jesus, D. Kochhann, W. Heinrichs-Caldas, M. M. Coelho \& V. M. F. Almeida-Val, 2016. Metabolic rate and thermal tolerance in two congeneric Amazon fishes: paracheirodon axelrodi Schultz, 1956 and Paracheirodon simulans Géry, 1963 (Characidae). Hydrobiologia. doi:10.1007/s10750-016-2649-2.

Couceiro, S. R. M., N. Hamada, B. R. Forsberg \& C. PadovesiFonseca, 2011. Trophic structure of macroinvertebrates in Amazonian streams impacted by anthropogenic siltation. Austral Ecology 36: 628-637.

Duarte, R. M., M. S. Ferreira, C. M. Wood \& A. L. Val, 2013. Effect of low $\mathrm{pH}$ exposure on $\mathrm{Na}^{+}$regulation in two cichlid fish species of the Amazon. Comparative Biochemistry and Physiology A 166: 441-448.
Franco-de-Sá, J. \& A. L. Val, 2014. Copper toxicity for Scinax ruber and Rhinella granulosa (Amphibia: Anura) of the Amazon: potential of biotic ligand model to predict toxicity in urban streams. Acta Amazonica 44: 491-498.

Gonzalez, R., C. Wood, R. Wilson, M. Patrick, H. Bergman, A. Narahara \& A. Val, 1998. Effects of water $\mathrm{pH}$ and calcium concentration on ion balance in fish of the Rio Negro, Amazon. Physiological Zoology 71: 15-22.

Hamada, N., J. L. Nessimian \& R. B. Querino, 2014. Insetos Aquáticos na Amazônia Brasileira: Taxonomia, Biologia e Ecologia. Editora do INPA, Manaus.

IPCC, 2007. AR4, WGI Report. Cambridge University Press, Cambridge.

Johannsson, O. E., D. S. Smith, H. Sadauskas-Henrique, G. Cimprich, C. M. Wood \& A. L. Val, 2016. Photo-oxidation processes, properties of DOC, reactive oxygen species (ROS), and their potential impacts on native biota and carbon cycling in the Rio Negro (Amazonia, Brazil). Hydrobiologia. doi:10.1007/s10750-016-2687-9.

Junk, W., M. Piedade, F. Wittmann, J. Schoengart \& P. Parolin, 2011. Amazonian Floodplain Forests: Ecophysiology, Biodiversity and Sustainable Management. Springer, Dordrecht.

Junk, W. J., P. B. Bayley \& R. E. Sparks, 1989. The flood pulse concept in River-Floodplain Systems. In Dodge, D. P. (ed.), Proceedings of the International Large River Symposium. Canadian Special Publication of Fisheries and Aquatic Sciences, Canada:110-127.

Kochhann, D., S. M. A. Brust, F. V. Domingos \& A. L. Val, 2013. Linking hematological, biochemical, genotoxic, and behavioral responses to crude oil in the amazon fish Colossoma macropomum (Cuvier, 1816). Archives of Environmental Contamination and Toxicology 65: 266-275.

Kochhann, D. \& A. L. Val, 2016. Social hierarchy and resting metabolic rate in the dwarf cichlid Apistogramma agassizii: the role of habitat enrichment. Hydrobiologia. doi:10. 1007/s10750-016-2806-7.

Lopes, A., P. Parolin \& M. T. F. Piedade, 2016a. Morphological and physiological traits of aquatic macrophytes respond to water chemistry in the Amazon basin: an example of the genus Montrichardia Crueg (Araceae). Hydrobiologia 766: 1-15.

Lopes, A., F. Wittmann, J. Schoengart, J. E. Householder \& M. T. F. Piedade, 2016b. Modeling of regional-and local-scale distribution of the genus Montrichardia Crueg. (Araceae). Hydrobiologia. doi:10.1007/s10750-016-2721-y.

Lucena, M. N., J. McNamara \& F. A. Leone, 2016. Gill $\left(\mathrm{Na}^{+}, \mathrm{K}^{+}\right)$-ATPase from the Amazon River shrimp, Macrobrachium amazonicum (Decapoda, Palaemonidae): effect of exogenous biogenic amines on enzyme activity in juveniles and adults. Hydrobiologia. doi:10.1007/s10750016-2753-3.

MacCormack, T. J., J. L. Robinson, V. M. F. Almeida-Val, A. L. Val \& W. R. Driedzic, 2016. Acclimation to hypercarbia protects cardiac contractility and alters tissue carbohydrate metabolism in the Amazonian armored catfish Pterygoplichthys pardalis. Hydrobiologia. doi:10.1007/s10750015-2496-6.

Martins, R. T., A. S. Melo, J. F. Gonçalves Jr, C. M. Campos \& N. Hamada, 2016. Effects of climate change on leaf 
breakdown by microorganisms and the shredder Phylloicus elektoros (Trichoptera: Calamoceratidae). Hydrobiologia. doi:10.1007/s10750-016-2689-7.

Nelson, J. \& A. L. Val, 2016. From the equator to the poles, a physiology section perspective on climate change. Fisheries 41: 409-411.

Oliveira, A. M. \& A. L. Val, 2016. Effects of climate scenarios on the growth and physiology of the Amazonian fish tambaqui (Colossoma macropomum) (Characiformes: Serrasalmidae). Hydrobiologia. doi:10.1007/s10750-0162926-0.

Prado-Lima, M. \& A. L. Val, 2016. Transcriptomic characterization of tambaqui (Colossoma macropomum, Cuvier, 1818) exposed to three climate change scenarios. PLoS ONE. doi:10.1371/journal.pone.0152366.

Schöngart, J. \& W. J. Junk, 2007. Forecasting the flood-pulse in Central Amazonia by ENSO-indices. Journal of Hydrology 335: 124-132.

Sioli, H., 1950. Das wasser im Amazonasgebiet. Forschung Fortschritt 26: 274-280.

Souza-Bastos, L. R., A. L. Val \& A. M. Wood, 2016. Are Amazonian fish more sensitive to ammonia? Toxicity of ammonia to eleven native species. Hydrobiologia. doi: 10 . 1007/s10750-015-2623-4.

Speers-Roesch, B., J. L. Robinson, A. L. Val, V. M. F. AlmeidaVal \& W. R. Driedzic, 2016. Interspecific dietary diversity has little influence on pathways of glucose metabolism in liver and heart of piranhas and pacus (family Serrasalmidae). Hydrobiologia. doi:10.1007/s10750-015-2562-0.

Tadei, W. P., I. B. Rodrigues, M. S. Rafael, R. T. M. Sampaio, H. G. Mesquita, V. C. S. Pinheiro, J. A. C. Zequi, R. A. Roque \& J. M. M. Santos, 2016. Adaptative processes, control measures, genetic background, and resilience of malaria vectors and environmental changes in the Amazon region. Hydrobiologia. doi:10.1007/s10750-016-2960-y.

Val, A. L. \& V. M. F. Almeida-Val, 1995. Fishes of the Amazon and Their Environments. Physiological and Biochemical Features. Springer, Heidelberg.

Val, A. L., K. R. M. Gomes \& V. M. F. Almeida-Val, 2015. Rapid regulation of blood parameters under acute hypoxia in the Amazonian fish Prochilodus nigricans. Comparative Biochemistry and Physiology 184: 125-131.

Val, A. L., P. M. Fearnside \& V. M. F. Almeida-Val, 2016. Environmental disturbances and fishes of the Amazon. Journal of Fish Biology 89: 192-193.

Wood, C. M., R. W. Wilson, R. J. Gonzalez, M. L. Patrick, H. L. Bergman, A. Narahara \& A. L. Val, 1998. Responses of an Amazonian teleost, the tambaqui (Colossoma macropomum) to low $\mathrm{pH}$ in extremely soft water. Physiological Zoology 71: 658-670. 